\title{
Time impacts of treating pervious concrete with sodium bicarbonate
}

\author{
Nara Almeida ${ }^{1 *}$ (D) and Liv Haselbach ${ }^{2}$
}

\begin{abstract}
Magnesium chloride $\left(\mathrm{MgCl}_{2}\right)$ deicers applications onto pervious concrete pavements can deteriorate the material, and studies investigate treatments to increase the concrete resistance to $\mathrm{MgCl}_{2}$ attacks. In this paper, pervious concrete specimens are subjected to a treatment with Sodium Bicarbonate $\left(\mathrm{NaHCO}_{3}\right)$ solution, which seems to accelerate concrete carbonation and might hamper chemical reactions between $\mathrm{MgCl}_{2}$ deicer and hydroxides in cement mortar. All specimens had their compressive strength tested and the time frames before and after treatment varied. Results show that at least 2 months should be given post curing before treatment to not harm the concrete, and longer post treatment periods may be beneficial.
\end{abstract}

Keywords: Pervious concrete, Sodium bicarbonate, Magnesium chloride, Deicer

\section{Introduction}

The use of deicer salts in solid or solution form onto pavements is a frequent practice in cold climate regions, since these salts are able to decrease the freezing temperatures of solutions $[1,2]$, which may speed the melting process of existing ice and also reduce the ice formation on streets, sidewalks, parking lots and other pavement surfaces. However, damages on both conventional and pervious concrete pavements have been reported after the application of deicers, including magnesium chloride $[3,4]$, which might be explained by complex physical and chemical interactions between the deicer and cementitious components in the concrete $[5,6]$.

Pervious concrete pavements are considered a sustainable solution for many pavement applications, especially located within urban areas. Besides the several environmental benefits related to the use of these pavements, such as reduction of runoff and prevention of heat island effects, pervious concrete might improve the traffic safety of roads and sidewalks and the proposed treatment might improve its durability under many conditions furthering

\footnotetext{
*Correspondence: almeidan@lafayette.edu

${ }^{1}$ Department of Civil and Environmental Engineering, Lafayette College,

740 High Street - \# 323 AEC, Easton, PA 18042, USA

Full list of author information is available at the end of the article
}

the resiliency of this type of pavement system [4]. However, there are uncertainties with regards to the use of pervious concrete in cold climate areas, not only because of the possible harms caused by deicers, but due to the freezing and thawing effect, too. These uncertainties are led by the assumption that those two factors might produce more damages, or at least damages that are harder to fix, on pervious concrete than on conventional concrete, due to the porous nature of the material. Impacts caused by freezing and thawing might be more significant on pervious concrete because its large percentage of void content allows the rainwater to pass through the pavement structure, and a considerable volume of rainwater may freeze within these voids. With respect to the deicer attacks, deicer solutions may accumulate in areas of difficult access, into the pores of the pervious concrete, and a high concentration of salt might stay in contact with the material for long periods of time, since part of the water in the deicer solution may evaporate or drain through the subbase layer and the soil.

Although the freezing and thawing effect contributes to the damages caused on pervious concrete, the structural impacts caused by deicers, including magnesium chloride, are more significant than the freezing and thawing effect alone $[2,7]$. It should also be noted that water 
expands after freezing and magnesium chloride deicers, specifically, reduces this icing pressure, in pervious concrete, more significantly if compared to other deicers, such as calcium chloride $\left(\mathrm{CaCl}_{2}\right)$ and sodium chloride $(\mathrm{NaCl})$, or even in comparison to pure water [2]. In other words, that means that the use of deicers is beneficial to the impacts caused by the ice formation and consequent freezing and thawing effect. However, the damages caused by the deicers themselves may be significant and deserve attention.

Some studies investigate the resistance of pervious concrete to the negative impacts of deicers. One of these studies states that deicer attacks to concrete might be reduced if the amount of hydroxides is also reduced in its cementitious components [6], since the reactions between deicers and hydroxides may form noncementitious materials, weakening the concrete $[8,9]$. In concrete, these hydroxides are usually calcium-based, formed after the hydration of free calcium oxide $(\mathrm{CaO})$ and other calcium oxide phases, such as alite (C3S), belite $(\mathrm{C} 2 \mathrm{~S})$ and tricalcium aluminate (C3A). Because free calcium oxide and its related phases represent a significant percentage of a typical Type I cement, it is suggested that using supplementary cementitious materials (SCM) or accelerating the concrete carbonation may reduce the formation of hydroxides [6].

Carbonation of concrete is typically produced by carbon dioxide sequestration from the air into the concrete [10], thus calcium-based carbonates are formed, replacing existing calcium-based hydroxides, which can significantly improve freeze-thaw and leaching resistance of concrete [11]. Based on aqueous complexation, it is assumed that this process could prevent the concrete cementitious components from reacting with deicers, however, natural carbonation is a long process that might take years until deeper portions of the concrete get significantly carbonated. For this reason, a novel method was proposed [12] and initially applied [13] with the aim to accelerate the concrete carbonation. The method consists of a topical treatment with a sodium bicarbonate $\left(\mathrm{NaHCO}_{3}\right)$ solution poured onto pervious concrete specimens, to promote chemical exchanges between the carbonate components of $\mathrm{NaHCO}_{3}$ and the free hydroxides of the cement paste (see Eq. 1, that shows calcium carbonate, sodium hydroxide and water as possible products of the sodium bicarbonate and calcium hydroxide reaction), accelerating the concrete carbonation and perhaps increasing its resistance to one specific deicer attack, magnesium chloride.

$$
\mathrm{NaHCO}_{3}+\mathrm{Ca}(\mathrm{OH})_{2}=\mathrm{CaCO}_{3}+\mathrm{NaOH}+\mathrm{H}_{2} \mathrm{O}(1)
$$

It was demonstrated that the treatment with sodium bicarbonate solution is effective in terms of the cement paste hydration acceleration, through thermogravimetric/differential thermal analyses (TG-DTA), X-ray diffraction (XRD), and scanning electron microscopy (SEM) tests [14] and concrete carbonation acceleration [12], through Potential of Hydrogen $(\mathrm{pH})$ changes in the solution and thermogravimetric analyses (TGA) of the concrete. However, there are still uncertainties with regards to possible harms to the concrete durability, due to leaching or changes in porosity, caused by the treatment itself or by the combination of the treatment with the magnesium chloride deicer. Also, sodium bicarbonate does not seem to deteriorate the environment, since it has been used in fish farming as the $\mathrm{pH}$ buffer of pond waters [15], but further studies on how the treatment might affect groundwaters overtime, may be considered. Future research may analyze the water under pavements in contact with different concentrations of $\mathrm{NaHCO}_{3}$, and products of its reaction with deicers and cement paste. Some studies included the treatment of pervious concrete with sodium bicarbonate and combined it with magnesium chloride applications $[13,16]$, and results reinforced this uncertainty, since it was not clear if the changes in the concrete's compressive strength were caused by the $\mathrm{NaHCO}_{3}$ solution, by the $\mathrm{MgCl}_{2}$ deicer or by a combination of treatment and deicer applications.

Due to this uncertainty, another study isolated the treatment with sodium bicarbonate on pervious concrete [17], without the deicer as an additional variable, and a relevant finding was that the aging factor, before and after the treatment, contributes to the material's changes in compressive strength $[13,16,17]$. It was demonstrated that the $\mathrm{NaHCO}_{3}$ treatment affects the concrete negatively if it starts too early after casting (about a month) [13], when compared with other specimens that were treated 2 months after casting $[13,16]$. In addition, specimens with higher compressive strength averages were presented, if more time was given between the end of the treatment and the compressive strength test performance [17]. There is also interest in treating pervious concrete with sodium bicarbonate for moss control, so studies into its impact on the concrete are useful for this additional application [18].

This article aims to test groups of pervious concrete specimens, summed with part of previously presented results [17], in order to produce statistically significant data with respect to the influence of the aging factor over the sodium bicarbonate treatment onto pervious concrete. That is to say, this article aims to find how much time is needed post curing before treatment to not harm the pervious concrete, as well as to verify if giving more time after the treatment may perhaps benefit the material. 


\section{Methods}

Thirty-six pervious concrete cylindrical specimens were cast in two different batches. The first batch was composed of 16 specimens cast in April of 2019 (Batch b) and the second batch was a group of 20 specimens cast in May of the same year (Batch c). In both batches, the same mix design was adopted and proportioned by mass, being 4 parts of limestone gravel measuring around $9.5 \mathrm{~mm}$ (3/8 in), 1 part of ordinary Type I-II Portland cement (63.8\% of $\mathrm{CaO}$ by mass) and 0.3 parts of tap water. Approximately $2850 \mathrm{~g}$ of fresh concrete was poured into cylindrical molds, which had $100 \mathrm{~mm}$ (4 in) of diameter and $200 \mathrm{~mm}$ ( $8 \mathrm{in})$ of height each. The compaction was performed manually, in one single lift [10], to mimic the field pervious concrete installation process. With the aid of a rubber mallet, the compaction into the molds was considered completed when the height of the specimens was reduced to $178 \mathrm{~mm}$ (7 in), so the specimens were covered with a plastic lid and cured for 7 days, in laboratory conditions of temperature and humidity $\left(23^{\circ} \mathrm{C}\right.$ or $74{ }^{\circ} \mathrm{F}$ and $56 \%$, respectively). Right after curing, the specimens were removed from the molds and left to dry under the same laboratory conditions for a few days (14 days for Batch b, 2 days for Batch c), before the density and the void content of each hardened pervious concrete specimens were verified [19]. After drying, all specimens were wrapped along their side surface with a special plastic sheet, leaving a lip of $5 \mathrm{~cm}$ ( 2 in) on the top, to allow the performance of experiments that involve pouring water or any solution onto the specimens [20].

Four months after casting (August for Batch b, September for Batch $\mathrm{c}$ ), half of the specimens (8 specimens from Batch b, 10 specimens from Batch c) were subjected to a treatment with carbonate laden waters produced in laboratory. The treatment consists of a sodium bicarbonate solution, $3 \%$ concentrated by mass, poured onto the tops of the cylindrical pervious concrete specimens, on two sets of 5 consecutive days, separated by 2 weekend days. Thirty milliliters of solution were poured daily onto each specimen, except in the first day of experiment and in the day right after the weekend, when $60 \mathrm{ml}$ of solution were poured, because the specimens were drier than in the other days. The other halves of the specimens received the same amount of tap water during the same periods of time, as a control, to be compared to the treated specimens. All specimens were left to dry for about a month after the treatment ended and then compressive strength tests were performed on all of them [21].

The idea of waiting 4 months after casting until starting the treatment with sodium bicarbonate was based on previous experiments performed in previous studies $[13,16]$, that presented uncertainties if pervious concrete decrease in strength could have been caused by an early sodium bicarbonate treatment, by an early $\mathrm{MgCl}_{2}$ deicer application or by a combination of both. Another study was performed, isolating the $\mathrm{NaHCO}_{3}$ treatment onto pervious concrete, without combining it with $\mathrm{MgCl}_{2}$ applications [17] and it was found that the time frame between the treatment and the compressive strength test performance was also very significant, so the data provided by this particular study [17] (Batch a) is also included in this paper, for comparison purposes, totaling 79 specimens. Batch a has 43 specimens cast in December of 2018 and treated with $\mathrm{NaHCO}_{3}$ in February of 2019, but the compressive strength tests were performed in March of 2020 to 20 of the 43 specimens, while for the other 23 specimens, the compressive strength test occurred in May of the same year. Batch a also had roughly half of the specimens subjected to tap water and the specimens' void content was also verified. Additional information about Batch a may be found in the paper that previously analyzed these specimens [17].

\section{Results}

In Table 1, average and standard deviation values of compressive strength and porosity are presented by groups of pervious concrete specimens, which are segregated by Batches ( $\mathrm{a}, \mathrm{b}$ or $\mathrm{c}$ ), by treatment (water or sodium bicarbonate) and by time frames - between casting and treatment start and between the end of the treatment and the compressive strength test performance. The second column of Table 1, which consists of an "Age Description" category, describes these time frames, that are given in months, therefore classifying a group of specimens as "2 $\mathrm{M}$ treat" and "1 $\mathrm{M}$ test" means that the material started to be treated approximately 2 months after casting and had its compressive strength test performed about 1 month after the treatment was concluded.

To better evaluate the results shown in Table 1, it is important to note that the porosity values present low standard deviations within each of all the batches, which means that the segregation by batch seems to also represent a segregation by porosity. It is widely known that pervious concrete compressive strength decreases with porosity increase [22] and because of that, the graphs presented in the results correlate compressive strength and porosity. However, the differences in compressive strength values do not appear to be influenced only by porosity or by batch, but also by the treatment and by the time frames or aging factors. For instance, results presented in Table 1 suggest a significant difference in compressive strength between the " $2.5 \mathrm{M}$ test" and the " 1 $\mathrm{M}$ test" specimens, within Batch a that were also treated with $\mathrm{NaHCO}_{3}$ solution. And these results confirm what previous studies concluded [17], which means that additional time after the sodium bicarbonate treatment may 
Table 1 Compressive strength and porosity values of groups of specimens, segregated by Batch, treatment and time framings

\begin{tabular}{|c|c|c|c|c|c|}
\hline $\begin{array}{l}\text { Batch and } \\
\text { Treatment }\end{array}$ & $\begin{array}{l}\text { Age } \\
\text { Description } \\
\text { (months) }^{\mathrm{a}}\end{array}$ & $\begin{array}{l}\text { \# of Days Between } \\
\text { Casting and Treatment } \\
\text { (start) }\end{array}$ & $\begin{array}{l}\text { \# of Days Between } \\
\text { Treatment (end) and } \\
\text { Testing }\end{array}$ & $\begin{array}{l}\text { Average Porosity } \\
(\%) \pm \text { Standard } \\
\text { Deviation }\end{array}$ & $\begin{array}{l}\text { Average Compressive } \\
\text { Strength }(\mathrm{MPa}) \pm \text { Standard } \\
\text { Deviation }\end{array}$ \\
\hline $\begin{array}{l}\text { Batch a } \\
\text { WATER }\end{array}$ & $\begin{array}{l}2 \mathrm{M} \text { treat } \\
0.5 \mathrm{M} \text { test }\end{array}$ & 64 & 13 & $25.2 \pm 0.5$ & $9.8 \pm 2.0$ \\
\hline $\begin{array}{l}\text { Batch a } \\
\mathrm{NaHCO}_{3}\end{array}$ & $\begin{array}{l}\mathbf{2} \mathbf{M} \text { treat } \\
\mathbf{1} \mathbf{M} \text { test }\end{array}$ & 64 & 24 & $25.3 \pm 0.5$ & $7.8 \pm 1.1$ \\
\hline $\begin{array}{l}\text { Batch a } \\
\text { WATER }\end{array}$ & $\begin{array}{l}2 \mathrm{M} \text { treat } \\
2.5 \mathrm{M} \text { test }\end{array}$ & 64 & 79 & $25.4 \pm 0.5$ & $10 \pm 1.9$ \\
\hline $\begin{array}{l}\text { Batch a } \\
\mathrm{NaHCO}_{3}\end{array}$ & $\begin{array}{l}2 \mathrm{M} \text { treat } \\
2.5 \mathrm{M} \text { test }\end{array}$ & 64 & 74 & $25.4 \pm 0.6$ & $11 \pm 2.3$ \\
\hline $\begin{array}{l}\text { Batch b } \\
\text { WATER }\end{array}$ & $\begin{array}{l}\mathbf{4 M} \text { treat } \\
\mathbf{1} \mathbf{M} \text { test }\end{array}$ & 125 & 34 & $23.4 \pm 0.6$ & $13 \pm 1.3$ \\
\hline $\begin{array}{l}\text { Batch b } \\
\mathrm{NaHCO}_{3}\end{array}$ & $\begin{array}{l}\mathbf{4} \mathbf{M} \text { treat } \\
\mathbf{1} \mathbf{M} \text { test }\end{array}$ & 125 & 33 & $23.6 \pm 0.5$ & $11 \pm 1.8$ \\
\hline $\begin{array}{l}\text { Batch c } \\
\text { WATER }\end{array}$ & $\begin{array}{l}\mathbf{4} \mathbf{M} \text { treat } \\
\mathbf{1} \mathbf{M} \text { test }\end{array}$ & 118 & 28 & $23.2 \pm 0.4$ & $11 \pm 1.5$ \\
\hline $\begin{array}{l}\text { Batch C } \\
\mathrm{NaHCO}_{3}\end{array}$ & $\begin{array}{l}\mathbf{4 M} \text { treat } \\
\mathbf{1} \mathbf{M} \text { test }\end{array}$ & 118 & 27 & $23.3 \pm 0.3$ & $12 \pm 1.5$ \\
\hline
\end{tabular}

a Age Description: Specimens classified as "X M treat" and "Y M test" were treated X months after casting and the compressive strength test was performed $\mathrm{Y}$ months after treatment conclusion

be beneficial to the pervious concrete. It is important to note that according to what is exposed in Table 1, the 4 months period between casting and treating the concrete of Batches b and c did not seem to improve the mechanical performance of the material, if compared to the 2-month timeframe previously tested $[13,16]$.

Due to the large number of independent variables, an analysis of variance (ANOVA) was performed, to establish the statistical significance of each of these variables on the influence of compressive strength change among all specimens. Based on Table 1 data, some specific independent variables were considered for the ANOVA. The categorical ones are the treatment (water or $\mathrm{NaHCO}_{3}$ ) and the "later compressive strength test" performance (specimens treated 2.5 months after casting are isolated from the others, treated less than 2.5 months after casting). The only numerical variable is the porosity, which shows similar averages and low standard deviations within batches. As seen in Table 2, the difference in treatments seems to explain $1.08 \%$ of the data, while the "later compressive strength test" performance has an effect size of $6.93 \%$. Lastly and as expected, porosity variation stands out as the most relevant variable, explaining $32 \%$ of the results.

In Figs. 1 and 2, it may be noticed that the average porosities seem to be grouped by similar values of specimens in Batches b and $c$ together, and higher and similar porosities of specimens in Batch a, separately. In both Figures, the specimens are segregated by batch, but Fig. 1 shows the ones treated with tap water and Fig. 2, those treated with sodium bicarbonate.

In Fig. 1, when only treated with tap water, a later performance of the compressive strength test (2.5M test) does not seem to affect the compressive strength of the concrete. However, in Fig. 2, Batch a specimens treated with sodium bicarbonate seems to have its compressive strength increased if the compressive strength test is performed 2.5 months later, again confirming what was concluded by previous research [17].

Based on the results presented in Fig. 2, another graph was plotted, isolating all the specimens treated with $\mathrm{NaHCO}_{3}$ and segregating them by the time frame

Table 2 ANOVA to explain changes in compressive strength - variables are treatment, porosity values and late compressive strength test performance

\begin{tabular}{lllllll}
\hline & Sum of squares & $\begin{array}{l}\text { Degrees of } \\
\text { freedom }\end{array}$ & Mean square & F-statistic & $P$-value & Effect size $\left(\eta^{2}\right)$ \\
\hline Treatment & 4.20 & 1 & 4.20 & 1.35 & $\mathbf{0 . 2 5 0}$ & $\mathbf{1 . 0 8 \%}$ \\
Porosity & 125 & 1 & 27.0 & 40.1 & $\mathbf{1 . 6 3 E}-\mathbf{0 8}$ & $\mathbf{3 2 . 0 \%}$ \\
Later C.S. test & 27.0 & 1 & 3.12 & 1.00 & $\mathbf{0 . 0 0 4 3 2}$ & $\mathbf{6 . 9 3 \%}$ \\
Error & 234 & 75 & & & 0.500 & \\
\hline
\end{tabular}




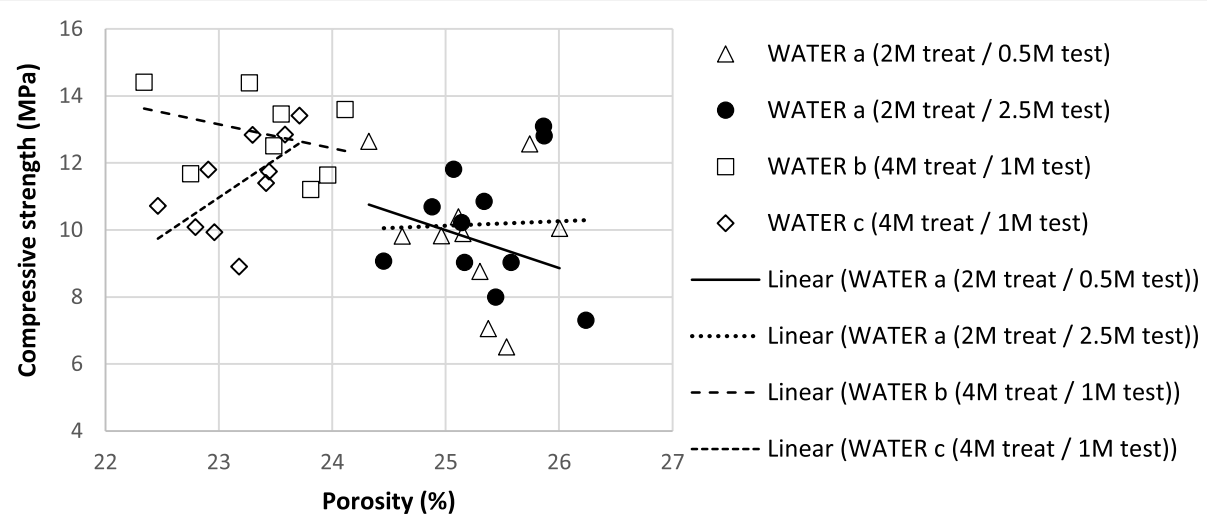

Fig. 1 Compressive strength versus porosity: water treated specimens, segregated by Batch ("X $M$ treat" $=$ treated $X$ months after casting; " $Y M$ test" $=$ tested $Y$ months after treatment ended)

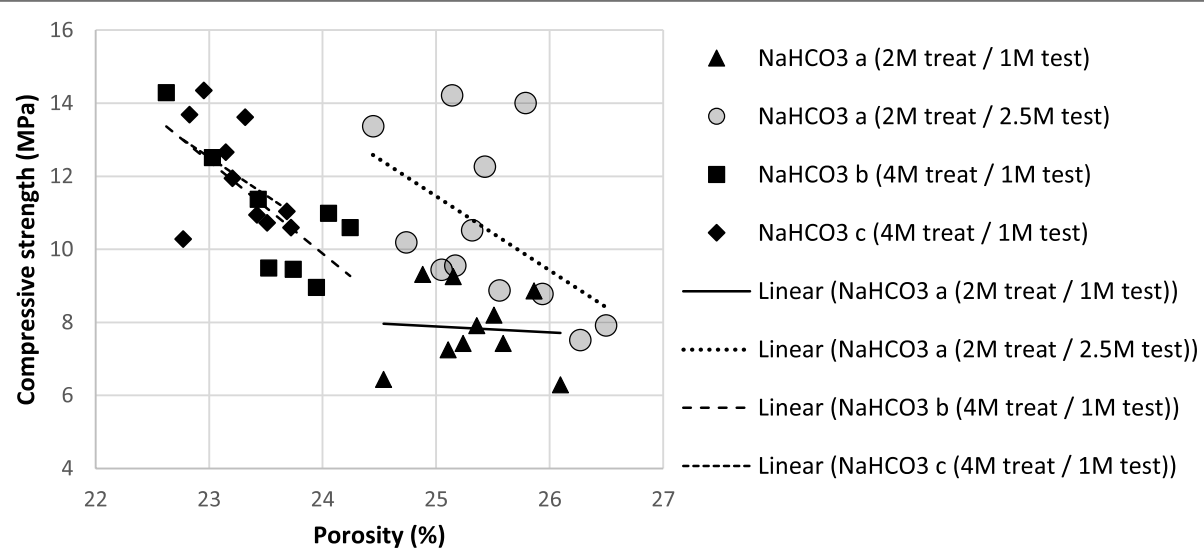

Fig. 2 Compressive strength versus porosity: $\mathrm{NaHCO}_{3}$ treated specimens, segregated by Batch ("X M treat" = treated $\mathrm{X}$ months after casting; " $Y \mathrm{M}$ test" $=$ tested $\mathrm{Y}$ months after treatment ended)

between the end of the treatment and the performance of the compressive strength test. The specimens that had their compressive test performed 2.5 months after the treatment ended $(2.5 \mathrm{M}$ test) are separated from those that had the test performance before 2.5 months after the last day of treatment $(<2.5 \mathrm{M}$ test), no matter when the treatment started. This graph is shown in Fig. 3, and the data appears to support the evidence that a later compressive strength test may be statistically significant among sodium bicarbonate treated specimens [17]. In other words, it seems that the $\mathrm{NaHCO}_{3}$ treatment requires time, so chemical reactions between the solution and the cementitious material in the concrete may occur and it might benefit the material's compressive strength.

In order to verify the statistical significance of a later compressive strength test among specimens treated with sodium bicarbonate, another analysis of variance (ANOVA) was performed, better explaining the differences in compressive strength values showed in Fig. 4. The ANOVA presented in Table 3 considers the porosity as a numerical variable and the later compressive strength test as a categorical variable (yes or no). Although the results still indicate a higher influence of the porosity over compressive strength (46.9\%), the later compressive strength test performance is statistically significant, with a low $p$-value (5.54 E-05), explaining $19.1 \%$ of the data.

Figure 4 shows a graph where the specimens treated with sodium bicarbonate and that had a later compressive strength test ( 2.5 months after treatment ended) are plotted against all other specimens, despite their treatment (water or sodium bicarbonate) or their aging factors.

In Table 4, another analysis of variance (ANOVA) was performed, so the statistical relevance of the late compressive strength test performance combined with the 


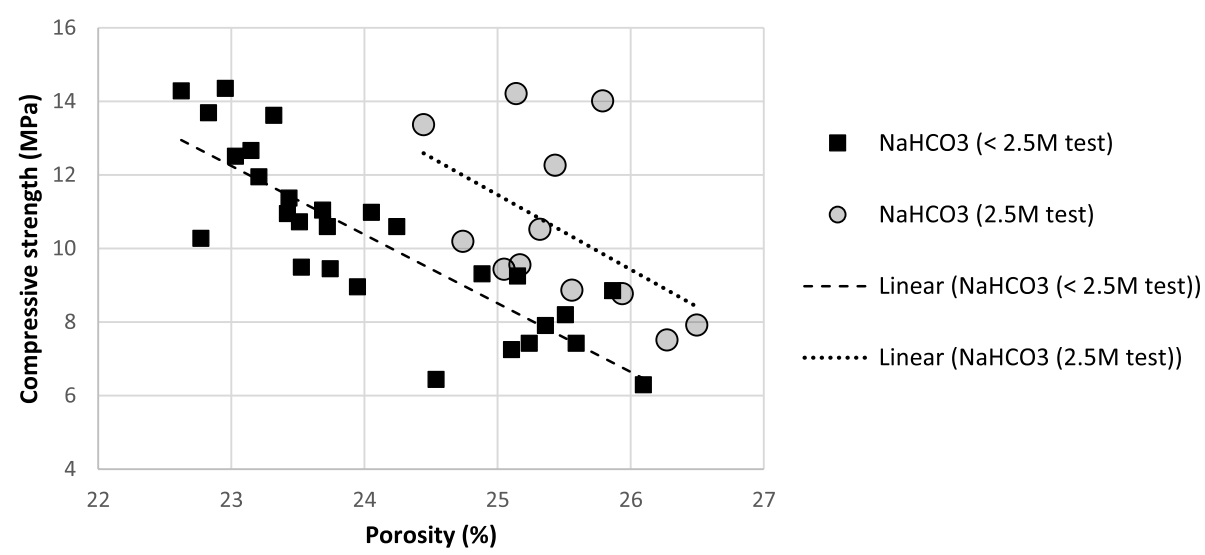

Fig. 3 Compressive strength versus porosity: $\mathrm{NaHCO}_{3}$ treated specimens, segregated by early or late compressive strength test performance ("X $\mathrm{M}$ treat" $=$ treated $\mathrm{X}$ months after casting; "Y M test" = tested $Y$ months after treatment ended)

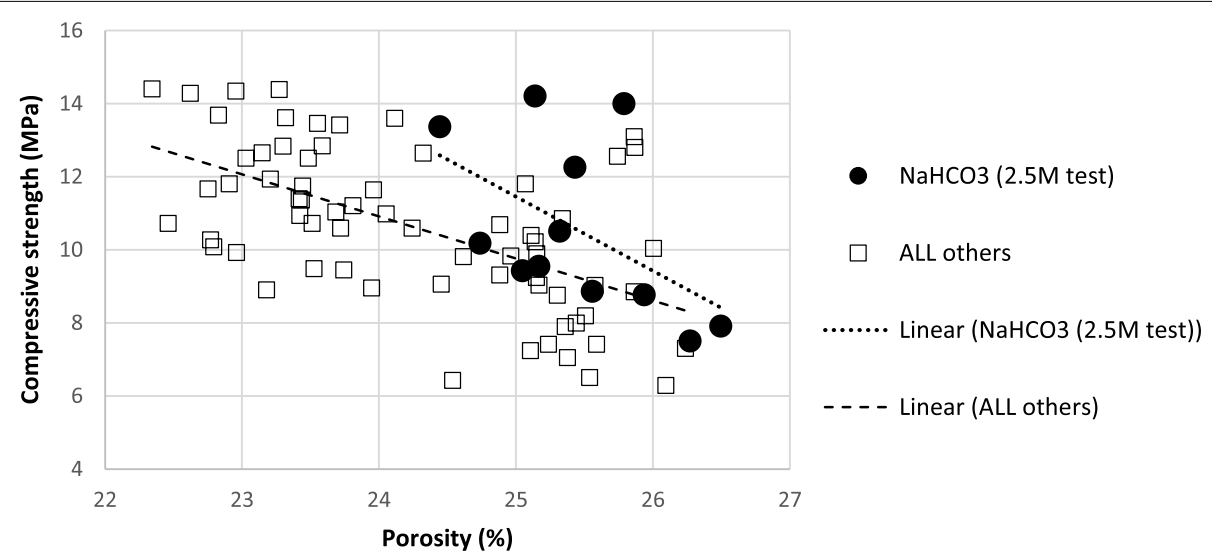

Fig. 4 Compressive strength versus porosity: All specimens, segregated by early or late compressive strength test performance ("X $M$ treat"= treated $\mathrm{X}$ months after casting; "Y M test" = tested $Y$ months after treatment ended)

Table 3 ANOVA to explain changes in compressive strength among $\mathrm{NaHCO}_{3}$ treated specimens, segregated by early or late compressive strength test performance

\begin{tabular}{lllllll}
\hline & Sum of squares & $\begin{array}{l}\text { Degrees of } \\
\text { freedom }\end{array}$ & Mean square & F-statistic & P-value & Effect size $\left(\eta^{2}\right)$ \\
\hline Porosity & 119 & 1 & 119 & 51.0 & $\mathbf{1 . 8 5 E - 0 8}$ & $\mathbf{4 6 . 9 \%}$ \\
Later C.S. test & 48.5 & 1 & 48.5 & 20.7 & $\mathbf{5 . 5 4 E - 0 5}$ & $\mathbf{1 9 . 1 \%}$ \\
Error & 86.5 & 37 & 2.34 & 1 & 0.5 & \\
\hline
\end{tabular}

Table 4 ANOVA to explain changes in compressive strength among all specimens, segregated by early or late compressive strength test performance

\begin{tabular}{lllllcc}
\hline & Sum of squares & $\begin{array}{l}\text { Degrees of } \\
\text { freedom }\end{array}$ & Mean square & F-statistic & $P$-value & $\begin{array}{l}\text { Effect size } \\
\left(\eta^{2}\right)\end{array}$ \\
\hline Porosity & 128 & 1 & 128 & 40.9 & $\mathbf{1 . 2 0 E - 0 8}$ & $\mathbf{3 2 . 5 3 \%}$ \\
Late C.S. test & 27.4 & 1 & 27.4 & 8.7 & $\mathbf{4 . 1 5 E}-03$ & $\mathbf{6 . 9 6 \%}$ \\
Error & 238 & 76 & 3.13 & 1 & 0.5 & \\
\hline
\end{tabular}


$\mathrm{NaHCO}_{3}$ treatment could be evaluated among all the other specimens, as previously illustrated in Fig. 4. Once more and again as expected, the porosity looms as the most relevant variable, influencing the changes in compressive strength. Even though, the late compressive strength test combined with the sodium bicarbonate treatment presents a low $p$-value (4.15 E-03), showing an effect size of $6.96 \%$.

\section{Discussion}

The results from this experiment endorse the ones described in previously published papers [13, 16, 17], suggesting that the treatment of pervious concrete with sodium bicarbonate solution seems to affect the compressive strength of the material, but the timeframes before and after the treatment must be taken into consideration. Particularly Figs. 2, 3 and 4 and Table 3 highlight the difference in compressive strength between treated specimens that had their compressive strength tested 2.5 months after the treatment ended, and other specimens, that had a smaller time frame between the end of the treatment and the compressive strength test performance. These outcomes suggest that at least 2 months after casting should be given for the curing process of the concrete, and that additional time, after the $\mathrm{NaHCO} 3$ treatment, should also be provided. This extra time may allow chemical reactions that accelerates concrete carbonation to occur, and this perhaps promotes the concrete resistance to deicer attacks, too.

\section{Conclusions}

The results presented are especially relevant because the treatment of pervious concrete with sodium bicarbonate is not only of interest of increasing concrete resistance to deicers, but also to its use for moss control. In summary:

1. At least 2 months after casting should be given until treating pervious concrete with sodium bicarbonate solution so that the treatment itself does not weaken the concrete.

2. More than 2 months between casting and starting the treatment does not appear to make any significant difference in compressive strength as compared to 2 months.

3. Longer periods before deicer application post treatment, such as the additional 2.5 months analyzed in this paper indicate that the treatments may aid in strengthening the concrete.

4. Since no test was performed with $\mathrm{MgCl}_{2}$ deicer, more research is needed to determine if the strength increases also will improve deicer resistance.
Abbreviations

ANOVA: Analysis of variance; C2S: Dicalcium silicate, or belite; C3A: Tricalcium aluminate; $\mathrm{C} 3 \mathrm{~S}$ : Tricalcium silicate, or alite; $\mathrm{CaCl}_{2}$ : Calcium chloride; $\mathrm{CaCO}_{3}$ : Calcium carbonate; $\mathrm{CaO}$ : Calcium oxide; $\mathrm{Ca}(\mathrm{OH})_{2}$ : Calcium hydroxide; $\mathrm{H}_{2} \mathrm{O}$ : Water; $\mathrm{MgCl}_{2}$ : Magnesium chloride; $\mathrm{NaCl}$ : Sodium chloride; $\mathrm{NaHCO}_{3}$ : Sodium bicarbonate, or sodium hydrogen carbonate; $\mathrm{NaOH}$ : Sodium hydroxide; $\mathrm{pH}$ : Potential of hydrogen; SCM: Supplementary cementitious materials; SEM: Scanning electron microscopy; TGA: Thermogravimetric analyses; TG-DTA: Thermogravimetric/differential thermal analyses; XRD: X-ray diffraction.

\section{Acknowledgements}

Thank you to Lamar University College of engineering, Jarod Jantz and Mateo Chevasco.

\section{Authors' contributions}

Almeida, Nara: Lab tests performance, data collection, data analysis, graphs, development of tables and figures, writing. Haselbach, Liv: Research idea, advising, data analysis, writing. The author(s) read and approved the final manuscript.

Funding

No funding was provided to this particular research phase.

Availability of data and materials

The datasets used and/or analyzed during the current study are available from the corresponding author on reasonable request.

\section{Declarations}

\section{Competing interests}

The authors declare that they have no competing interests.

\section{Author details}

${ }^{1}$ Department of Civil and Environmental Engineering, Lafayette College, 740 High Street - \# 323 AEC, Easton, PA 18042, USA. ² Department of Civil and Environmental Engineering, Lamar University, P.O. Box 10024, Beaumont, TX 77710, USA.

Received: 14 June 2021 Accepted: 6 October 2021

Published online: 30 October 2021

References

1. Farnam Y, Wiese A, Bentz D, Davis J, Weiss J (2015) Damage development in cementitious materials exposed to magnesium chloride deicing salt. Constr Build Mater 93:384-392

2. Ma H, Yu H, Tian J, Tan Y, Da B (2019) The physical and mechanical properties of chloride-based deicers at $0 \sim-30^{\circ} \mathrm{C}$. Constr Build Mater 211:721-729

3. Xie N, Dang Y, Shi X (2019) New insights into how MgCl2 deteriorates Portland cement concrete. Cem Concr Res 120:244-255

4. Xie N, Akin M, Shi X (2019) Permeable concrete pavements: a review of environmental benefits and durability. J Clean Prod 210:1605-1621

5. Lee H, Cody R, Cody A, Spry P (2000) Effects of various deicing chemicals on pavement concrete deterioration. In: Presented at the Center for Transportation Research and Education Mid-Continent Transportation Symposium, Ames, lowa, May 15-16 Retrieved from: https://trid.trb.org/ view/655607

6. Suraneni P, Azad VJ, Isgor OB, Weiss WJ (2016) Deicing salts and durability of concrete pavements and joints. Concr Int 38(4):48-54

7. Tsang C, Shehata M, Lotfy A (2016) Optimizing a test method to evaluate resistance of pervious concrete to cycles of freezing and thawing in the presence of different deicing salts. Materials (Basel) 9(11):878

8. Qiao C, Suraneni P, Chang MT, Weiss J (2018) Damage in cement pastes exposed to $\mathrm{MgCl}_{2}$ solutions. Mater Struct 51:74

9. Ghazy A, Bassuoni MT (2017) Resistance of concrete to different exposures with chloride-based salts. Cem Concr Res 101:144-158

10. Verbeck GJ (1958) Carbonation of hydrated Port-land cement. West Conshohocken: ASTM International, pp 17-36 
11. Chen T, Gao X (2020) Use of carbonation curing to improve mechanical strength and durability of pervious concrete. ACS Sustain Chem Eng 8:3872-3884

12. Haselbach L, Thomle J (2014) An alternative mechanism for accelerated carbon sequestration in concrete. Sustain Cities Soc 12:25-30

13. Almeida N, Haselbach $L$ (2021) Proposed method to reduce magnesium chloride deicer damage to pervious concrete. J Cold Reg Eng 35(3 (ASCE)):06021004

14. Wang Y, He F, Wang J, Hu Q (2019) Comparison of effects of sodium bicarbonate and sodium carbonate on the hydration and properties of Portland cement paste. Materials 12:1033

15. Nindarwi DD, Rochman AN, Tsany MRN, Rachmawati V, Masithah ED (2019) Study of calcium hydroxide $\left(\mathrm{Ca}(\mathrm{OH})_{2}\right)$ and sodium bicarbonate $\left(\mathrm{NaHCO}_{3}\right)$ treatment in the dynamics of $\mathrm{pH}, \mathrm{COD}, \mathrm{N} / \mathrm{P}$ ratio and plankton abundance. J Aquac Fish Health 8(2):72-79

16. Almeida N, Haselbach L (2020a) Accelerating carbonation in pervious concrete for improved deicer resistance. In: ASCE international conference on transportation \& development. Seattle, WA, May 26-29, 2020 (published in August $31^{\text {st }}$ 2020)
17. Almeida N, Haselbach L (2020b) Early treatment of pervious concrete with carbonate laden waters. In: International low impact development (LID), Maryland, July 19-22, 2020 (presented virtually in July of 2020)

18. NRMCA (National Ready-Mixed Concrete Association) (2018) Pervious concrete pavement maintenance and operations guide.

19. ASTM (ASTM International) C1754 / C1754M-12 (2012) Standard test method for density and void content of hardened pervious concrete, West Conshohocken

20. ISO (International Standard) 17785-1 (2016) Testing methods for pervious concrete - part 1: infiltration rate, Geneva

21. ASTM (ASTM International) C39 / C39M-18 (2018) Standard test method for compressive strength of cylindrical concrete specimens, West Conshohocken

22. ACl (American Concrete Institute) (2010) Report on pervious concrete 522R-10. ACl Committee 522, Farmington Hills

\section{Publisher's Note}

Springer Nature remains neutral with regard to jurisdictional claims in published maps and institutional affiliations.

\section{Submit your manuscript to a SpringerOpen ${ }^{\circ}$ journal and benefit from:}

- Convenient online submission

- Rigorous peer review

- Open access: articles freely available online

- High visibility within the field

- Retaining the copyright to your article

Submit your next manuscript at $\boldsymbol{\nabla}$ springeropen.com 